\title{
Kendali Kecepatan Motor Listrik Satu Phasa Berdasarkan Suhu Ruangan
}

\section{Single Phase Electric Motor Speed Control Based on Room Temperature}

\author{
I Made Adiswara Wirama1, I Made Aris Dharma Putra², I Made Weda Maharta Putra ${ }^{3}$, \\ Anak Agung Ngurah Made Narottama ${ }^{4}$, Anak Agung Ngurah Gde Sapteka ${ }^{5 *}$ \\ 1,2,3,4,5 Politeknik Negeri Bali \\ Bukit Jimbaran, Badung, Bali, (0361) 701981 \\ ramawiramas@gmail.com ${ }^{1}$, arisdharma009@gmail.com ${ }^{2}$,wedamaharta07@gmail.com ${ }^{3}$, \\ narottama@pnb.ac.id ${ }^{4}$, sapteka@pnb.ac.id $5^{*}$
}

\begin{abstract}
Abstrak - Sistem pengendalian suhu ruangan secara otomatis diyakini mampu memberikan penghematan tanpa mengurangi performansinya. Pengendalian suhu ruangan dilakukan dengan mengatur kecepatan putaran motor exhaust fan dengan SCR speed controller. Hal ini sangat diperlukan untuk menghemat pengeluaran listrik. Dalam mengkoneksikan antara sensor suhu dengan SCR speed controller diperlukan mikrokontroler Arduino Uno sebagai pengolah data keluaran dari sensor sehingga dapat mengendalikan speed controller 1 dengan keluaran tegangan 180 volt dan speed controller 2 dengan keluaran tegangan 200 volt. Alat ini cocok digunakan untuk mengatur suhu di ruangan tertutup agar selalu stabil.
\end{abstract}

Kata Kunci: Arduino Uno, ds18b20, Exhaust fan, SCR speed control, PZEM-004T.

\begin{abstract}
An automated room temperature control is a way to do savings without reducing its performance. The temperature control is done by adjusting the rotation speed of the exhaust fan motor using an SCR speed controller. This mechanism will give a great advantage on power usage reduction. To connect the temperature sensor with the SCR speed controller, an Arduino Uno microcontroller is used as a processor of the outputs from the sensor so it can control the 1st speed controller with 180 Volt and the 2nd speed controller with 200 Volt. This tool is suitable for maintaining the temperature of a closed room temperature.
\end{abstract}

Keywords: Arduino Uno, ds18b20, Exhaust fan, SCR speed control, PZEM-004T.

\section{Pendahuluan}

Sistem pengkondisian udara adalah suatu fasilitas tata udara yang digunakan untuk mengontrol suhu lingkungan dari suatu wilayah tertutup, apakah itu bangunan, gudang, atau kendaraan komersial [1]. Seiring dengan berkembangnya pembangunan infrastruktur, sistem ini menjadi sangat penting dalam masyarakat dan telah hadir dalam berbagai produk dan model seperti air conditioner, kulkas, dan juga pendingin udara kendaraan, seperti pada mobil dan bus. Pada beberapa pemakaian seperti ruangan budidaya, suhu harus berada pada kondisi tertentu untuk menjaga subjek budidaya tumbuh dalam kondisi optimal. Sebagai contohnya, jamur tiram memiliki syarat tumbuh dengan suhu $16^{\circ} \mathrm{C}-22^{\circ} \mathrm{C}$ [2]. Fermentasi tempe bekerja pada suhu antara $30^{\circ} \mathrm{C}-37^{\circ} \mathrm{C}$. Sistem pengatur suhu ruangan untuk fermentasi tempe sudah pernah dibuat, yakni

TELKA, Vol.7, No.1, Mei 2021, pp. 21 28

ISSN (e): 2540-9123

ISSN (p): 2502-1982 
dengan mempergunakan 8 buah lampu pijar 30 watt dan juga motor kipas 12 volt DC [3]. Begitu banyak kebutuhan terhadap kestabilan suhu ruangan menjadikan sistem pengkondisian udara menjadi subjek yang cukup menarik untuk ditelaah.

Penelitian sebelumnya mengenai pembuatan sistem pengkondisian udara berbasis mikrokontroler juga sudah banyak dikembangkan. Percobaan sistem yang menggunakan sensor DS18B20 dan motor fan 12 volt DC menunjukkan hasil berupa sistem yang sudah beroperasi dengan baik. Pada suhu terendah yaitu $27,30^{\circ} \mathrm{C}$, kipas pendingin masih dalam keadaan off, serta pada suhu $29,15^{\circ} \mathrm{C}$ pun kipas pendingin masih dalam keadaan off, tetapi ketika suhu yang terdeteksi oleh sensor di atas $32^{\circ} \mathrm{C}$, maka berdasarkan hasil data kipas mulai bergerak dan berputar, semakin suhu lebih tinggi dari suhu $32^{\circ} \mathrm{C}$ maka kipas akan berputar semakin kencang sesuai dengan setpoint yang diprogram pada Arduino Uno [4]. Namun pada publikasi tersebut tidak menjelaskan tentang pemakaian daya dan kualitas udara yang dihasilkan.

Penelitian kontrol pendingin ruangan yang memanfaatkan fuzzy logic juga sudah pernah dilakukan. Pada publikasi tersebut dijelaskan masukan sistem yang digunakan adalah data suhu yang berasal dari sensor LM35 dan data keberadaan orang yang berasal dari sensor PIR. Keluaran sistem berupa pengaturan kecepatan motor fan arus searah dalam tiga tingkat kecepatan. Algoritma logika fuzzy yang diterapkan dimulai dari tahap pendeteksian keberadaan orang. Apabila tidak terdapat orang, maka motor fan akan selalu pada kondisi mati [5]. Hasil dari penelitian tersebut juga hanya menampilkan data kesesuaian rancangan algoritma dengan kinerja yang dilakukan sistem, yang memang sudah beroperasi sesuai dengan harapan. Data mengenai pemakaian daya dan kualitas udara yang dihasilkan tidak dijelaskan.

Dalam prelimineary research, pemakaian daya dan efisiensi adalah salah satu indikator untuk menjamin sistem yang baru mampu memberikan hasil yang lebih baik daripada sistem yang konvensional. Seperti contohnya pada sistem pengaturan suhu PHO (pre-heating oven) yang sebelumnya mempergunakan kontaktor yang lebih konvensional diganti dengan SSR (solid state relay) yang lebih baru. Sistem yang lebih baru ini ternyata mampu memberikan hasil lebih baik dari segi jangka waktu pemakaian kontak. Peningkatan kinerja PHO disebabkan tidak adanya kerusakan peralatan pengendali SSR (sebelumnya menggunakan magnetic contactor yang mengalami kerusakan akibat life time setiap 2 bulan). PHO sudah mengalami masa running time yang cukup lama sejak adanya perbaikan (11 tahun) dengan desain life time SSR berkisar 15 tahun [6]. Publikasi tersebut menunjukkan bahwa sistem yang lebih baru memang mampu memberikan kelebihan dan keuntungan ketimbang sistem yang konvensional seperti kontaktor pada contoh publikasi tersebut.

Berdasarkan latar belakang permasalahan tersebut, makalah ini menguraikan hasil uji efisiensi dari model pengkondisian suhu ruangan yang mempergunakan kendali perangkat mikrokontroler secara otomatis. Sistem yang dibangun menggunakan mesin kipas pembuang panas (exhaust fan) dengan tegangan kerja 220 volt AC. Sistem mampu mendeteksi suhu ruangan sebagai parameter pengendalian mesin secara otomatis. Sebagai perbandingan, model sistem yang pada umumnya digunakan adalah metode on/off yakni apabila suhu mencapai titik tertinggi, maka mesin akan hidup pada kecepatan putaran tertinggi hingga suhu menetap di sekitar setpoint-nya tercapai. Sistem ini sering terdapat pada kulkas konvensional. Namun berbeda dengan itu, sistem yang diteliti disini adalah model pengendalian mesin dengan metode penyesuaian kecepatan berdasarkan perubahan suhu setiap saat.

Pemanfaatan kipas pembuang panas dapat menjadi salah satu solusi sistem pengkondisian udara. Penyesuaian kecepatan berdasarkan suhu diyakini mampu mengurangi pemakaian daya dan kelebihan usaha yang tidak perlu. Pemakaian daya berkala diukur untuk menguji penghematan daya. Suhu ruangan berkala diukur untuk menguji efektifitas performansi sistem sehingga diperoleh karakteristik dan kelebihan dari sistem ini. 


\section{Metode Penelitian}

Penelitian ini dilakukan dengan metode kuantitatif. Data didapatkan dengan menguji coba alat pada beberapa kondisi suhu ruangan sistem yang telah dibuat. Kemudian, data yang telah tampil pada serial monitor dicatat secara langsung dan dilakukan tabulasi data untuk pengujian dan analisis lebih lanjut. Pengujian dilakukan dengan beberapa langkah, dimulai dari menghidupkan alat dengan menyuplai Arduino pada tegangan 5 volt DC dan motor dengan tegangan 220 volt AC. Kemudian dilakuan pencatatan data pada serial monitor. Data yang keluar pada serial monitor mencakup suhu, tegangan arus dan daya per jam. Pengujian dilakukan selama 15 menit. Data yang terlihat pada serial monitor dimasukkan ke dalam tabel dan dilakukan perhitungan untuk mengetahui $\mathrm{kWh}$ masing-masing sakelar yang digunakan tergantung dengan suhunya.

\subsection{Rangkaian Elektronik Sistem}

Diagram balok dari sistem pengontrolan kecepatan putaran motor exhaust fan berdasarkan perubahan temperatur ruangan ditampilkan pada Gambar 1. Mikrokontroler Arduino Uno tersambung ke 3 buah switch sebagai output dan setiap channel bermuara pada SCR masing masing. Keluaran dari setiap SCR dari ketiga channel ini memiliki pengaturan tegangan mulai dari tingkat terendah pada level 1 sebesar 180 volt, level 2 sebesar 200 volt, hingga tingkat tertinggi pada tegangan tanpa pengurangan, yakni level 3 pada tegangan 220 volt untuk menyuplai motor fan. Motor ini hanya boleh disuplai oleh satu channel dalam satu waktu. Sensor suhu berfungsi untuk mengukur suhu ruangan secara berkala. Jenis sensor suhu yang digunakan adalah DS18B20 yakni sensor digital dengan hasil pengukuran sinyal analog sudah dikonversi menjadi data digital bertipe word 16 bit pada sisi sensor tersebut.

Pada suhu di bawah $30^{\circ} \mathrm{C}$, motor exhaust fan mati. Pada rentang suhu dari $30^{\circ} \mathrm{C}$ hingga $32^{\circ} \mathrm{C}$, motor disuplai dengan tegangan 180 volt. Kemudian rentang selanjutnya pada $32^{\circ} \mathrm{C}$ hingga $34^{\circ} \mathrm{C}$ diberi suplai tegangan 200 volt. Terakhir, apabila suhu mencapai $34^{\circ} \mathrm{C}$ ke atas, maka motor disuplai dengan tegangan penuh pada 220 volt. Gambar 1 menunjukkan diagram balok sistem.
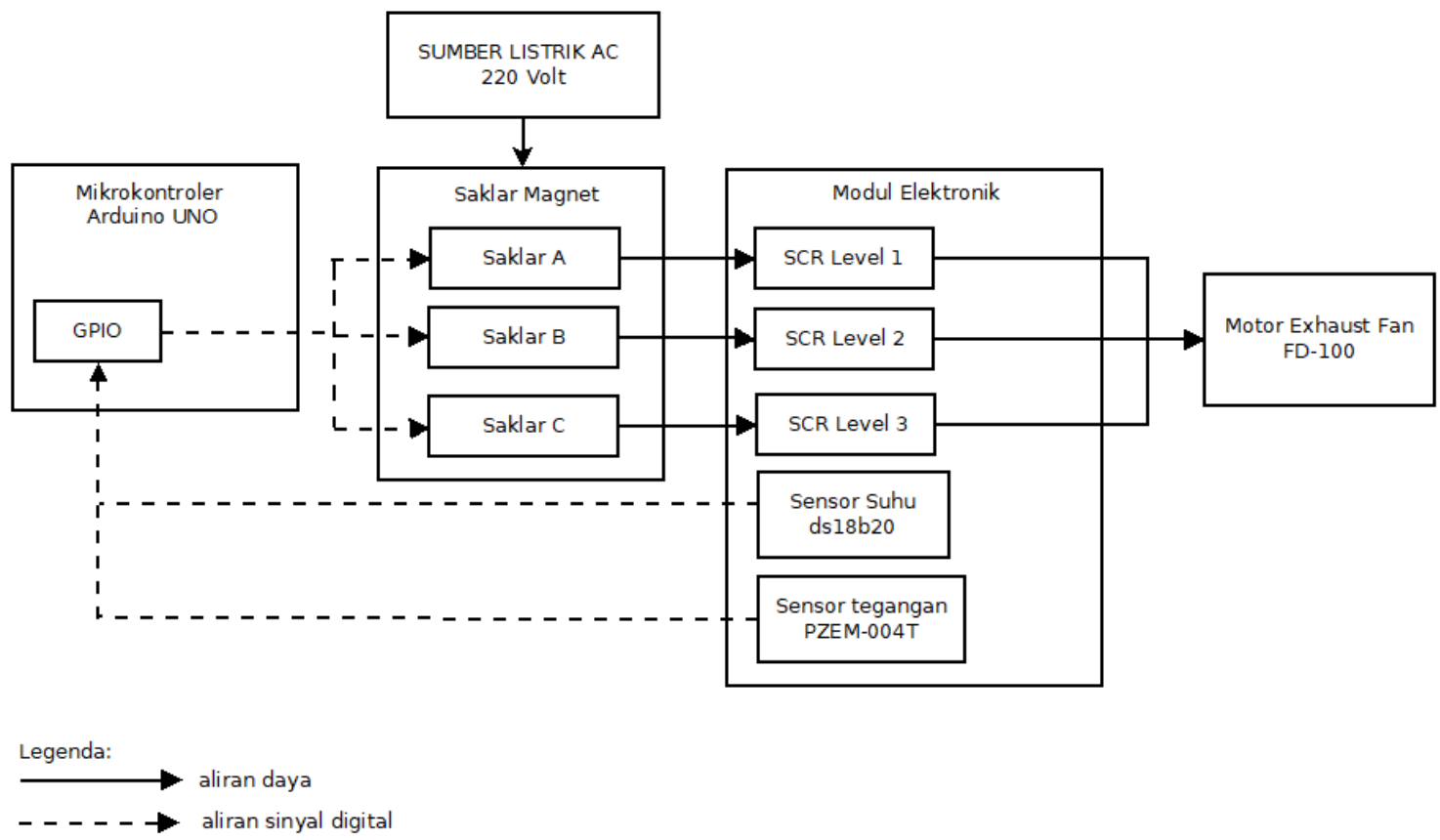

Gambar 1. Diagram balok sistem.

Pengontrolan kecepatan motor exhaust fan dilakukan oleh serangkaian komponen SCR yang berperan sebagai driver motor dengan tegangan yang telah disesuaikan. Prinsipnya adalah 
pemodifikasian tegangan setiap saat yang disuplai ke motor exhaust fan. Penurunan tegangan efektif mampu mengurangi kecepatan putaran motor exhaust fan. Pada keluaran dari SCR dipasang sensor pengukur besaran listrik PZEM-004T yang telah terhubung dengan serial monitor pada laptop untuk pengamatan data besaran listrik. Model motor exhaust fan yang digunakan adalah FD-100 dengan spesifikasi kecepatan rotasi pada tegangan 220 volt sebesar 2800 RPM. Rangkaian elektronik yang digunakan dalam sistem ditunjukkan pada Gambar 2.

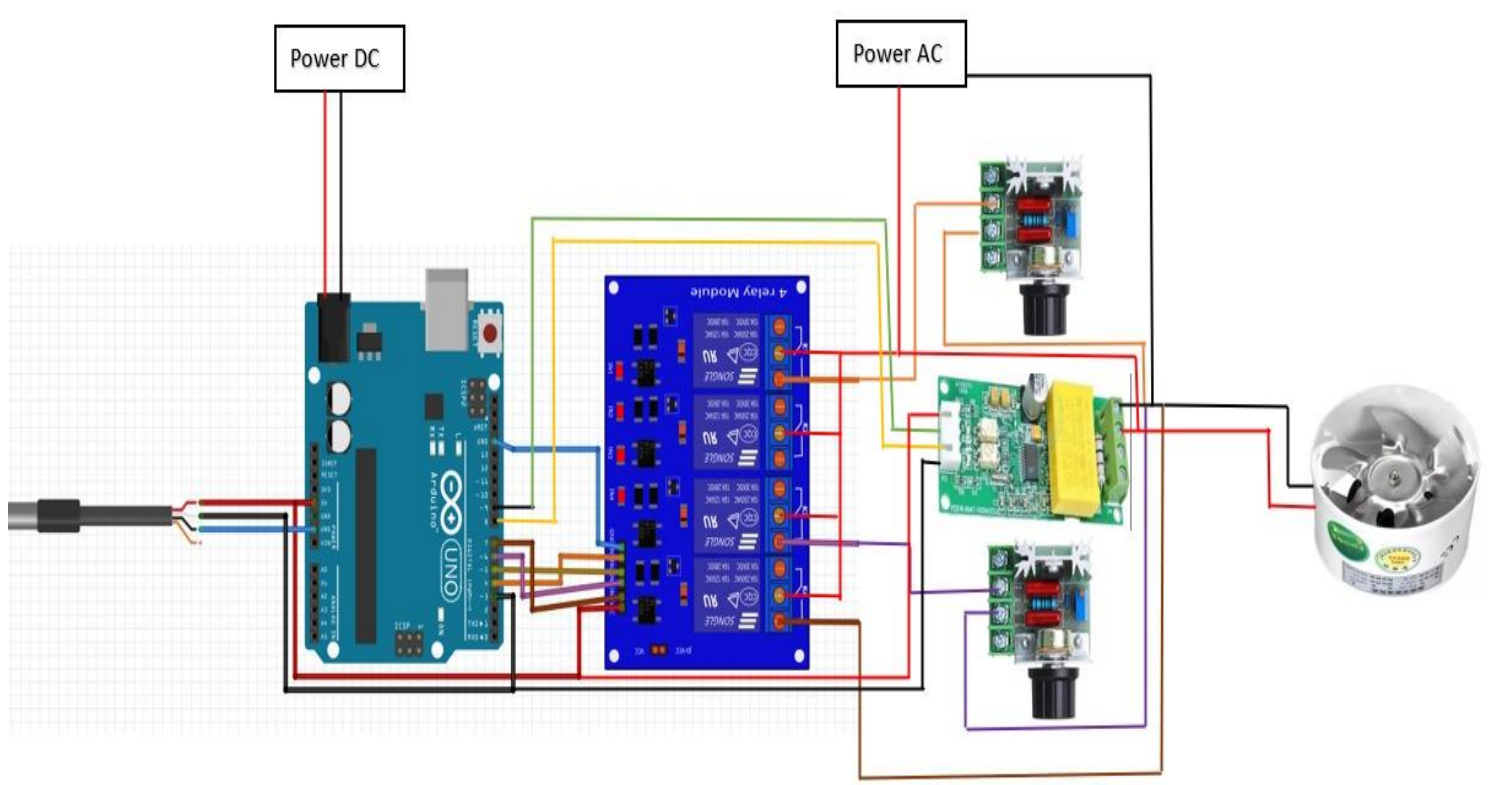

Gambar 2. Rangkaian elektronik sistem.

\subsection{Diagram Alir Sistem}

Algoritma sistem mengacu kepada proses pengumpulan data uji yang dibutuhkan, yakni temperatur ruangan dan daya listrik yang digunakan motor. Proses tersebut berlangsung dalam durasi 15 menit pengujian. Gambar 3 memperlihatkan diagram alir sistem yang menjabarkan proses tersebut secara detail.

\section{Hasil dan Pembahasan}

\subsection{Perangkat Keras Sistem}

Perangkat keras yang dihasilkan untuk menunjang kebutuhan sistem seperti yang telah dijelaskan pada bab sebelumnya adalah berupa sebuah kotak panel dan miniatur ruangan buatan sendiri. Kotak panel memuat serangkaian pengkabelan elektronik yang dibutuhkan sistem seperti yang telah dijelaskan pada bagian rangkaian elektronik. Miniatur ruangan dipasang motor exhaust fan dengan sensor suhu terpasang ke dalamnya untuk mensimulasikan pembuangan panas ruangan oleh motor tersebut. Ruangan bersifat tertutup, sehingga murni pembuangan panas dilakukan oleh motor tersebut. Gambar 4 menunjukkan miniatur ruangan. 


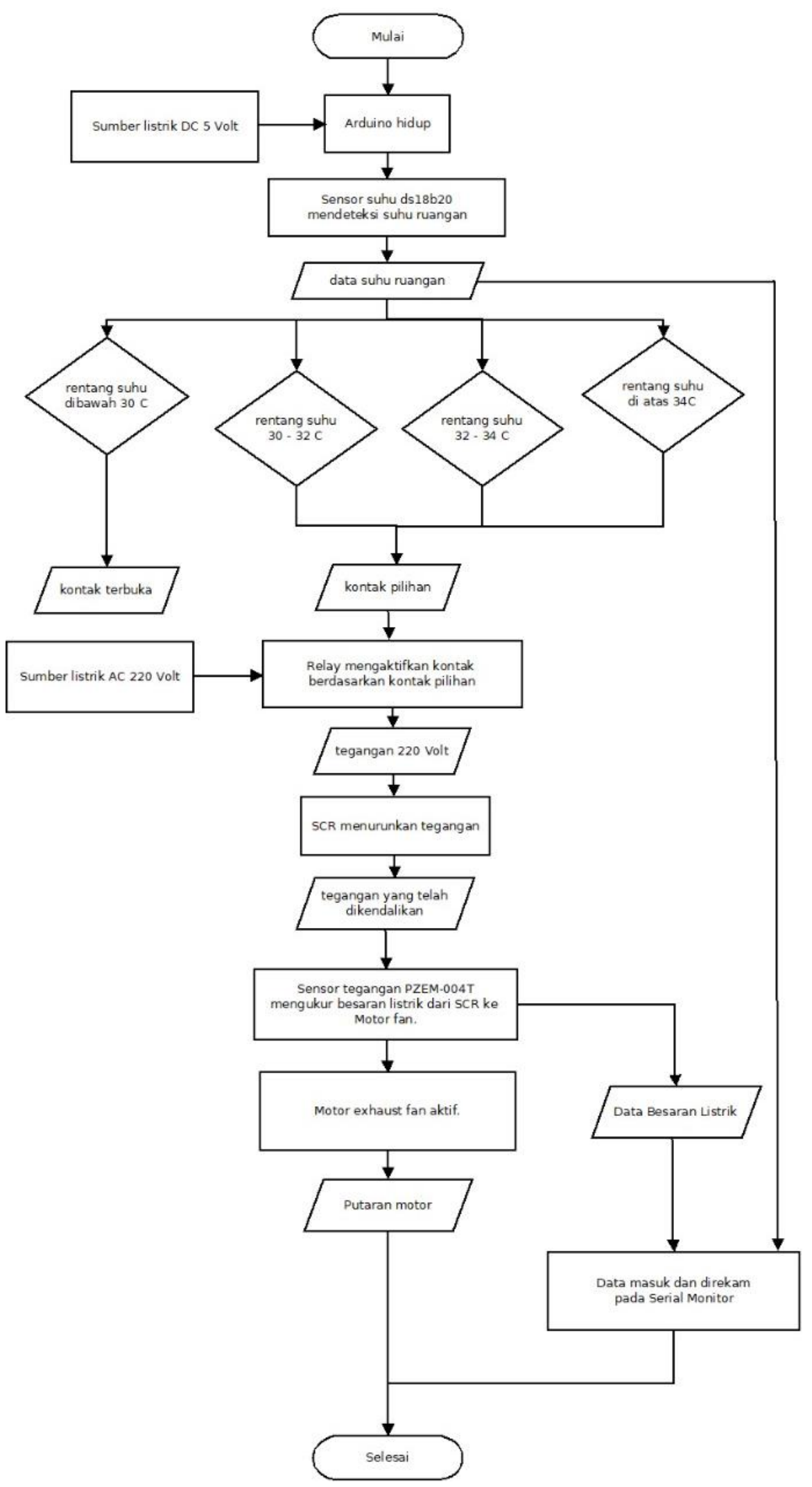

Gambar 3. Langkah pengambilan data pada alat. 


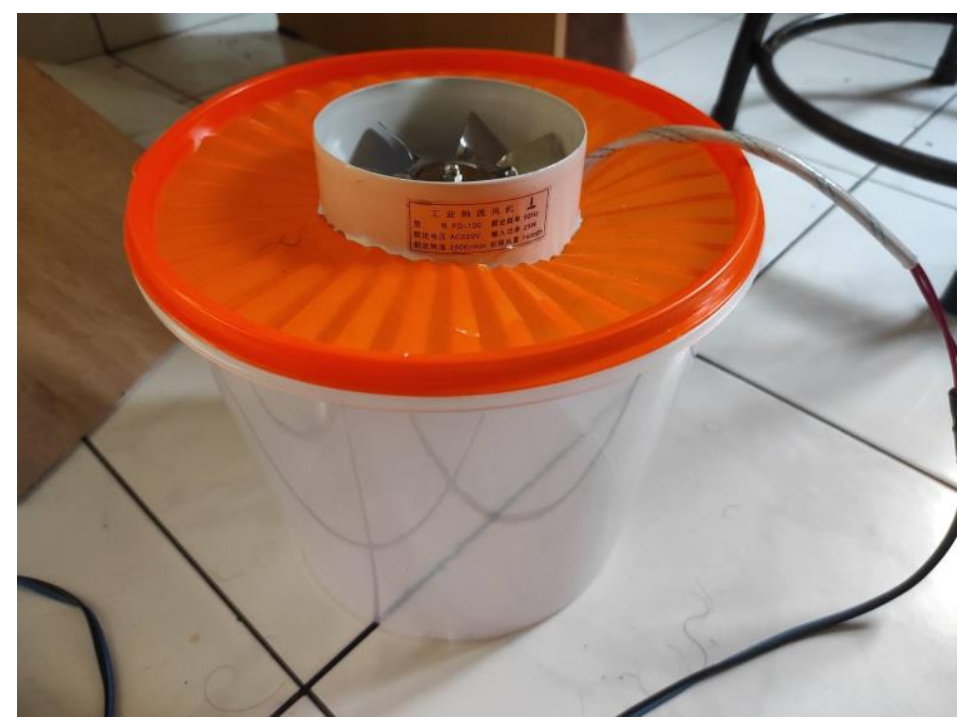

Gambar 4. Miniatur ruangan.

\subsection{Analisis}

Data pengujian mencakup suhu ruang miniatur dan juga nilai besaran-besaran listrik dari aliran listrik yang disuplai ke dalam motor fan. Data ini ditunjukkan pada Tabel 1 dengan menggunakan Persamaan (1).

$$
W h=\frac{P \times j a m / h a r i}{1000}
$$

$W h \quad=$ penggunaan energi per jam dalam satuan $\mathrm{kWh}$

$P \quad$ = daya yang digunakan oleh alat dalam satuan watt

Dengan menggunakan perhitungan dapat diketahui masing-masing $\mathrm{kWh}$. Pada suhu di bawah $30^{\circ} \mathrm{C}$ alat dalam keadaan mati sehingga daya yang dipakai 0 sehingga $\mathrm{kWh}$ yang terpakai adalah 0 . Untuk suhu $30^{\circ} \mathrm{C}$ sampai dengan $32^{\circ} \mathrm{C}$ tegangan yang keluar adalah antara 170 volt sampai 190 volt dengan rata-rata data yang dipakai sesuai dengan tabel 1 dan hasil rata-ratanya pada Tabel 2 yaitu 8,9 watt, sehingga penggunaan per jam yaitu $0,0089 \mathrm{kWh}$. Untuk suhu di atas $32^{\circ} \mathrm{C}$ sampai $34^{\circ} \mathrm{C}$ tegangan yang keluar di atas 190 volt sampai 200 volt dengan rata-rata data yang dipakai sesuai dengan Tabel 1 dan hasil rata-ratanya pada Tabel 2 sebesar 11,26 watt, sehingga penggunaan per jam sebesar $0,0113 \mathrm{kWh}$ dan untuk suhu di atas $34^{\circ} \mathrm{C}$ menggunakan tegangan 201 volt sampai 230 volt dengan rata-rata daya yang dipakai sesuai dengan Tabel 1 sebesar 13,62 watt dan hasil rata-rata energi pada Tabel 2 sebesar 0,0136 kWh.

Tabel 1. Hasil pengujian.

\begin{tabular}{cccc}
\hline Suhu $\left({ }^{\circ} \mathrm{C}\right)$ & Tegangan $(\mathrm{V})$ & Arus $(\mathrm{A})$ & Daya $(\mathrm{W})$ \\
\hline 30,94 & 178,5 & 0,07 & 8,7 \\
30,87 & 179,1 & 0,07 & 8,8 \\
30,81 & 179,9 & 0,07 & 8,9 \\
30,75 & 180,3 & 0,07 & 8,9 \\
30,69 & 180,5 & 0,07 & 8,9 \\
30,62 & 180,5 & 0,07 & 9 \\
30,56 & 180,6 & 0,07 & 8,9 \\
30,75 & 180,6 & 0,07 & 8,9 \\
31,06 & 180,5 & 0,07 & 8,9
\end{tabular}




\begin{tabular}{|c|c|c|c|}
\hline Suhu $\left({ }^{\circ} \mathrm{C}\right)$ & Tegangan $(\mathrm{V})$ & Arus (A) & Daya $(\mathrm{W})$ \\
\hline 31,37 & 180,5 & 0,07 & 9 \\
\hline 31,62 & 180,5 & 0,07 & 8,9 \\
\hline 31,94 & 180,6 & 0,07 & 9 \\
\hline 32,38 & 190,6 & 0,08 & 10,5 \\
\hline 32,63 & 190,6 & 0,08 & 10,5 \\
\hline 32,81 & 199,4 & 0,08 & 11,5 \\
\hline 33,00 & 199,7 & 0,08 & 11,5 \\
\hline 33,13 & 199,7 & 0,08 & 11,5 \\
\hline 33,25 & 198,0 & 0,08 & 11,2 \\
\hline 33,38 & 197,3 & 0,08 & 11,2 \\
\hline 33,50 & 197,8 & 0,08 & 11,2 \\
\hline 33,63 & 198,5 & 0,08 & 11,3 \\
\hline 33,69 & 198,5 & 0,08 & 11,3 \\
\hline 33,75 & 199,1 & 0,08 & 11,4 \\
\hline 33,88 & 199,4 & 0,08 & 11,4 \\
\hline 33,94 & 199,7 & 0,08 & 11,5 \\
\hline 34,06 & 200,0 & 0,08 & 11,6 \\
\hline 34,13 & 211,4 & 0,09 & 14,1 \\
\hline 34,25 & 223,0 & 0,1 & 16,2 \\
\hline 34,25 & 223,0 & 0,1 & 16,3 \\
\hline 34,31 & 223,1 & 0,1 & 16,3 \\
\hline 34,44 & 223,1 & 0,1 & 16,3 \\
\hline 34,5 & 223,1 & 0,1 & 16,3 \\
\hline 34,56 & 223,1 & 0,1 & 16,3 \\
\hline 34,63 & 223,1 & 0,1 & 16,3 \\
\hline 34,69 & 223,1 & 0,1 & 16,3 \\
\hline 34,63 & 223,2 & 0,1 & 16,3 \\
\hline 34,56 & 223,2 & 0,1 & 16,3 \\
\hline
\end{tabular}

Tabel 2. Hasil Perhitungan.

\begin{tabular}{ccc}
\hline Tegangan $(\mathrm{V})$ & Daya rata-rata $(\mathrm{W})$ & Energi $(\mathrm{kWh})$ \\
\hline 0 & 0 & 0 \\
$170 \sim 189$ & 8,9 & 0,0089 \\
$190 \sim 200$ & 11,26 & 0,0113 \\
$201 \sim 220$ & 13,62 & 0,0136 \\
\hline
\end{tabular}

\section{Kesimpulan}

Dari Tabel 1 dapat terlihat bahwa semakin tinggi suhu maka energi dan daya yang digunakan semakin besar. Hal ini disebabkan oleh suhu ruangan yang digunakan meninggi dan membuat alat bekerja lebih keras dan energi yang terpakai lebih banyak. Dapat juga dilihat pada Tabel 2, dalam hasil perhitungan terdapat perbedaan energi yang digunakan pada tegangan tertentu. Disini semakin tinggi tegangan yang digunakan, maka semakin besar energi yang digunakan.

\section{Referensi}

[1] B. Y. Husodo and N. A. Br. Siagian, "Analisa Audit Konsumsi Energi Sistem HVAC (Heating, Ventilasi, Air Conditioning) Di Terminal 1A, 1B, dan 1C Bandara SoekarnoHatta," Jurnal Teknologi Elektro Universitas Mercu Buana, vol. 5, no. 1, pp. 49-58, Januari 2014. 
[2] M. Ajie Putranto and M. Yamin, "Pengendalian Suhu Ruang pada Budidaya Jamur Tiram dengan Karung Goni Basah," Jurnal Keteknikan Pertanian, vol. 26, no. 2, pp. 137-142, Oktober 2012.

[3] R. P. Yunas and A. B. Pulungan, "Sistem Kendali Suhu dan Kelembaban pada Proses Fermentasi Tempe," Jurnal Teknik Elektro dan Vokasional, vol. 6, no. 1, pp. 103-113, Januari 2020.

[4] A. Sumardiono and A. Siswanto, "Kontrol Kestabilan Suhu Ruangan Menggunakan Sensor DS18DB20 Berbasis Mikrokontroler ATMEGA 328," SYNTAX Jurnal Informatika, vol. 6, no. 1, pp. 30-36, November 2017.

[5] S. Sadi and T. Budiawan, "Kontrol Pendingin Ruangan (Fan) dengan Logika Fuzzy Menggunakan Atmega 8535, LM35 Dan PIR," TELKA, vol. 2, no. 2, pp. 94-105, November 2016.

[6] E. Kustiawan, "Meningkatkan Efisiensi Peralatan Dengan Menggunakan Solid State Relay (SSR) Dalam Pengaturan Suhu Pack Pre-Heating Oven (PHO)," Jurnal STT YUPPENTEK, vol. 9, no. 1, pp. 1-6, April 2018. 